\title{
EFFICIENCY OF ARTIFICIAL HYBRIDIZATION IN SOYBEAN DURING THE SUMMER DEPENDING ON TEMPERATURE AND RELATIVE HUMIDITY
}

\author{
EFICIÊNCIA DA HIBRIDAÇÃO ARTIFICIAL EM SOJA DURANTE O VERÃO \\ DEPENDE DA TEMPERATURA E UMIDADE RELATIVA
}

\author{
Éder MATSUO ${ }^{1}$; Tuneo SEDIYAMA ${ }^{2}$; Cosme Damião CRUZ $^{3}$; \\ Sérgio Hermínio BROMMONSCHENKEL ${ }^{4}$; Silvana da Costa FERREIRA ${ }^{5}$; \\ Gustavo Sessa FIALHO ${ }^{6}$
}

1. Professor, Doutor, Instituto de Ciências Exatas e Tecnológicas, Universidade Federal de Viçosa - UFV, Rio Paranaíba, MG, Brasil. edermatsuo@ufv.br; 2. Professor, Doutor, Departamento de Fitotecnia - UFV, Viçosa, MG, Brasil; 3. Professor, Doutor, Departamento de Biologia Geral - UFV, Viçosa, MG, Brasil; 4. Professor, Doutor, Departamento de Fitopatologia - UFV, Viçosa, MG, Brasil; 5. Professora, Doutora, Instituto de Ciências Biológicas e da Saúde - UFV, Rio Paranaíba, MG, Brasil; 6. Professor, Doutor, Instituto de Física e Matemática, Departamento de Matemática e Estatística, Universidade Federal de Pelotas, Pelotas, RS, Brasil.

\begin{abstract}
Hybridization is an important improvement method used in the soybean culture. However, there is little information on the recommended relative moisture and air temperature degree for artificial pollination. Therefore, this study aimed to determine the efficiency of artificial hybridization between soybean parents according to different periods of the day. Artificial pollination of 14 hybrid combinations occurred in greenhouse in three periods of the day. The parents were: TMG 801, TMG 803, BRSGO 7560, BRS Valiosa RR, Agua-Marinha RR and NK 7059 RR. The studied variables were: relative moisture, air temperature, number of days to flowering, performed artificial pollination, pods without sepal, produced seeds, germinated seeds, hybrid plants and percentage of pods without sepals. Data were submitted to normality and homogeneity of variance test, analysis of variance, Tukey, Scheffé and $\chi 2$ tests, and correlation analysis. Six hundred and seventy-two artificial pollinations were performed. From which were obtained 436 pods without sepals and approximately $90 \%$ of produced seeds was hybrid. The results indicated that artificial pollinations performed in January, with parent used in this study, were more efficient in the period from 10:00 a.m. to 12:00 a.m., with mean relative moisture of $34.1 \%$ and mean temperature of $38.5^{\circ} \mathrm{C}$ and $2: 00$ a.m. to $4: 00$ p.m. with $30.7 \%$ and $41.6{ }^{\circ} \mathrm{C}$ respectively for relative moisture and means of temperature.
\end{abstract}

KEYWORDS: Glycine max. Improvement. Genetic variability.

\section{INTRODUCTION}

Higher production and grain yield in the soybean (Glycine $\max (\mathrm{L}$.$) Merr.) culture has been$ observed the last years. In the 1976/1977 growing season, 6.95 thousand hectares were cultivated, where 12.15 thousand tons of soybean were produced, resulting in $1,748 \mathrm{~kg}$ mean yield $\mathrm{ha}^{-1}$ (CONAB, 2011). Thirty-seven years later, 81.5 million tons of soybean were produced in 27.7 million hectares in the 2012/2013 growing season, resulting in $2,933 \mathrm{~kg}$ mean yield $\mathrm{ha}^{-1}$ (CONAB, 2013).

The considerable increase in soybean production and yield is a result of the persistent role of genetic improvement programs in developing and recommending cultivars, of farmers and researchers in several correlated areas with technology and production. Breeders have used hybridization in the development of new soybean cultivars (MIYASAKA; SILVA, 1958; SEDIYAMA et al., 2005). With hybridization between genetically different parents, populations with higher genetic variability can be developed, which allows the application of appropriate evaluation methods and selection of genotypes with superior phenotypes (BORÉM et al., 2009). The main aspects that must be considered to optimize hybridization and hybrid seed production process are: operator skill, environment, pests, diseases, flowering synchronization of progenitors and plant vigor (SEDIYAMA et al., 2005; BORÉM et al., 2009). The ideal environment to perform artificial hybridization in soybean plants may vary depending on the region and work conditions available to the breeder (SEDIYAMA et al., 2005). In other words, the environmental conditions can determine the hour of the day for pollen collection and highest and lowest efficiency in hybridizations (SEDIYAMA et al., 1981; SEDIYAMA et al., 2005; BORÉM et al., 2009). High or low relative air moisture and temperature at night, among several factors, may reduce the crossing rate (JOHNSON; BERNARD, 1963). Moreover, direct sunstroke or high relative moisture may impair the success of hybridizations (SEDIYAMA et al., 1985). In the literature, there is 
limited information on the magnitude of relative moisture and air temperature for achievement of higher numbers of pods and hybrid seeds. Thus, the purpose of this study was to determine the efficiency of soybean artificial hybridization according to different periods of the day.

\section{MATERIAL AND METHODS}

Artificial hybridization activities were performed in greenhouse of the Soybean Genetic
Improvement Program of the Department of Plant Science, at the Universidade Federal de Viçosa, Viçosa, Minas Gerais State, Brazil (2045'14" S; 42 ${ }^{\circ} 52^{\prime} 54 " \mathrm{~W}$; $640 \mathrm{~m}$ altitude), in the 2009/2010 growing season (Seed sowing: Dec. $8^{\text {th }}, 2009$ to Jan. $9^{\text {th }}, 2010$; Artificial pollinations: Jan. $29^{\text {th }}, 2010$ to Feb. $\left.19^{\text {th }}, 2010\right)$. The parents were: TMG 801, TMG 803, BRSGO 7560, BRS Valiosa RR, ÁguaMarinha RR and NK 7059 RR (Table 1).

Table 1. Some phenotypes of the agromorphological traits parents used in crossing block, Viçosa-MG, 2009/2010

\begin{tabular}{|c|c|c|c|c|}
\hline \multirow[b]{2}{*}{ Parents } & \multicolumn{4}{|c|}{ Characteristics } \\
\hline & Relative Maturity & Flower color & Pubescence color & $\begin{array}{c}\text { Glyphosate } \\
\text { Response }\end{array}$ \\
\hline NK 7059 RR & 6.6 & White & Grey & Resistant \\
\hline BRSGO 7560 & 7.5 & Purple & Tawny & Susceptible \\
\hline BRS Valiosa RR & 8.1 & Purple & Tawny & Resistant \\
\hline TMG 801 & 8.2 & Purple & Tawny & Susceptible \\
\hline TMG 803 & 8.7 & White & Tawny & Susceptible \\
\hline Água-Marinha RR & 8.7 & White & Tawny & Resistant \\
\hline
\end{tabular}

Aiming at flowering synchronization of plants in the crossing block, parent seed sowing was performed at different times in pots containing 3 $\mathrm{dm}^{3}$ soil, containing $1 / 3$ of organic matter. Sowing began on Dec. $8^{\text {th }}, 2009$ and ended on Jan. $9^{\text {th }}, 2010$, with a two-day interval (totalizing 17 seasons). Cultivar BRSGO 7560 was sown in the three last planting only (Jan. $5^{\text {th }}, 2010$, Jan. $7^{\text {th }}, 2010$ and Jan. $\left.9^{\text {th }}, 2010\right)$, due to unavailability of seeds at installation of crossing block. In each season, at development stage V1 (FEHR; CAVINESS, 1977), thinning to two plants per pot was carried out. At stage V4 (FEHR; CAVINESS, 1977), the apical meristem was removed, aiming to reduce the necessity of plant tutoring (TANCREDI et al., 2004). Subsequently, plants of the crossing block were grown according to culture recommendations (EMBRAPA, 2008).

Pollinations of 14 hybrid combinations (Table 2) were performed in three periods of the day (H1: 8:00 - 10:00 a.m., H2: 10:00 - 12:00 a.m. and H3: 2:00 - 4:00 p.m.), according to the hybridization process mentioned by Sediyama et al. (2005) and Borém et al. (2009).

Table 2. Hybrid combinations used in crossing block, Viçosa-MG, 2009/2010

\begin{tabular}{llll}
\hline Hybrid combinations & & Hybrid combinations \\
\cline { 1 - 1 } TMG 801 x BRS Valiosa RR & & TMG 803 x BRSGO 7560 \\
TMG 801 x Água-Marinha RR & & BRSGO 7560 x BRS Valiosa RR \\
TMG 801 x NK 7059 RR & & BRSGO 7560 x Água-Marinha RR \\
TMG 803 x BRS Valiosa RR & BRSGO 7560 x NK 7059 RR \\
TMG 803 x Água-Marinha RR & Água-Marinha RR x BRS Valiosa RR \\
TMG 803 x NK 7059 RR & NK 7059 RR x BRS Valiosa RR \\
TMG 803 x TMG 801 & NK 7059 RR x Água-Marinha RR \\
\hline
\end{tabular}


Aiming at identifying hybrid plants, parents presenting dominant phenotypic pattern over the feminine ones were used as masculine parents. The phenotypic patterns used as markers were: hypocotyl color, flower color, pubescence color and/or glyphosate tolerance. Sepal absence was used as phenotypic marker of pods originating from a flower submitted to artificial pollination process.

Magnitude of relative moisture and air temperature was recorded in all periods and days in which artificial pollination was carried out. Other analysed variables were: number of days to flowering, number of pollinations performed, number of pods without sepals, number of produced seeds, number of germinated seeds, number of hybrid plants and percentage of pods without sepals $\left\{\right.$ PPWS $_{\%}=[$ (Number of pods without sepals/Number of performed pollinations)*100]\}. The percentage of pods without sepals was obtained in each period and hybrid combination.

After harvest and attainment of the number produced seeds, were planted at least of the $50 \%$ seeds produced in trays with sand (trays with $39 \mathrm{~cm}$ length $\mathrm{x} 26 \mathrm{~cm}$ width $\times 5 \mathrm{~cm}$ depth) was carried out, separated according to hybrid combination and period of day in which artificial pollination was performed. Determination of number of hybrid plants was carried out based on hypocotyl color, pubescence color and/or glyphosate tolerance.

Relative moisture and air temperature data were analysed based on descriptive statistics: number of days which artificial pollination was carried out, mean, minimum and maximum values, coefficient of variation, variance, standard deviation and distribution with normality test carried out according to the Lilliefors methodology $(p \leq 0.05)$. Data from number of days to flowering were initially submitted to analysis of variance considering the completely randomized design unbalanced (seventeen replications for NK 7059 RR, BRS Valiosa RR, TMG 801, TMG 803 and Água-Marinha RR and three replication for BRSGO 7560), each experimental unit was represented by the average of two plants. Next, Tukey test considering unequal number of replications were applied for comparison of means at 5\% probability. The homogeneity of values of number of performed pollinations, number of pods without sepal, number of produced seeds, number of germinated seeds and number of hybrid plants among the three pollination periods were tested by Chi-square test $\left(\chi^{2}\right)$, at 1 and $5 \%$ probability. To analyse the three pollination periods according to means of the 14 hybrid combinations were initially carried out the Lilliefors normality test and Cochran homogeneity of variance test, at $5 \%$ probability. Next, analysis of variance (considering the completely randomized design whith fourteen replications and each experimental unit was represented by a hybrid combination) and Scheffé test were applied for comparison of mean contrast at $5 \%$ probability. The analyses were carried out in the Assistat Program (SILVA, 2002) and in the Genes Program (CRUZ, 2013).

\section{RESULTS AND DISCUSSION}

The results of the descriptive analysis for temperature and relative air moisture (Table 3) indicated normal distribution for two variables according to three pollination periods by Lilliefors test $(p \leq 0.05)$. It was noticed that means for air temperatures in periods $\mathrm{H} 1, \mathrm{H} 2$ and $\mathrm{H} 3$ were 32.8 ${ }^{\circ} \mathrm{C}, 38.5{ }^{\circ} \mathrm{C}$ and $41.6{ }^{\circ} \mathrm{C}$, respectively, and the magnitude of means for relative moisture in periods $\mathrm{H} 1, \mathrm{H} 2$ and $\mathrm{H} 3$ were $45.7 \%, 34.1 \%$ and $30.7 \%$, respectively. These results indicated tendency of temperature increase and relative air moisture reduction along the day.

Table 3. Descriptive statistic for temperature (TA), in ${ }^{\circ} \mathrm{C}$, and relative air moisture (RM), in $\%$, according to three hybridization periods (H1, H2 and H3), in greenhouse, Viçosa-MG, 2009/2010

\begin{tabular}{ccccccccc}
\hline $\begin{array}{c}\text { TA or RM / } \\
\text { Periods }^{1}\end{array}$ & $\begin{array}{c}\text { Number of } \\
\text { days }^{2}\end{array}$ & Mean & Min. & Max. & $\begin{array}{c}\text { Coefficient } \\
\text { of variation }\end{array}$ & Variance & $\begin{array}{c}\text { Standard } \\
\text { deviation }\end{array}$ & $\mathrm{D}^{3 \text { and } 4}$ \\
\hline TA - H1 & 11 & 32.8 & 30.0 & 37.0 & 7.31 & 5.7636 & 2.4008 & $0.1788^{\text {ns }}$ \\
TA - H2 & 19 & 38.5 & 33.0 & 42.0 & 5.58 & 4.6359 & 2.1531 & $0.0928^{\text {ns }}$ \\
TA - H3 & 15 & 41.6 & 38.0 & 43.5 & 3.38 & 1.9881 & 1.4099 & $0.1934^{\text {ns }}$ \\
RM - H1 & 11 & 45.7 & 39.0 & 56.5 & 11.62 & 28.2682 & 5.3168 & $0.1728^{\text {ns }}$ \\
RM - H2 & 19 & 34.1 & 29.0 & 45.0 & 12.47 & 18.0994 & 4.2543 & $0.1356^{\text {ns }}$ \\
RM - H3 & 15 & 30.7 & 27.5 & 35.5 & 6.61 & 4.1381 & 2.0342 & $0.1531^{\text {ns }}$ \\
\hline
\end{tabular}

${ }^{1}$ H1: 8:00 - 10:00 a.m., H2: 10:00 - 12:00 a.m. and H3: 2:00 - 4:00 p.m.; ${ }^{2}$ Number of days which artificial pollination was carried out;

${ }^{3}$ Statistic D of Lilliefors test; ${ }^{4 \text { ns }}$ : non-significant at $5 \%$ probability. 
The normality (Lilliefors) and homogeneity of variance (Cochran) tests indicated that it is possible to analyse data of number of days to flowering considering normal distribution and with homogeneity of variance, respectively. The parents: NK 7059 RR and BRSGO 7560 presented lower values of number of days to flowering, whereas, TMG 803 showed the highest mean (Table 4). This is due to the agronomic characteristic of each parents, mainly according to the region of adaptation. This difference was evidenced because they are from different maturity groups and they were sown under the same environmental conditions (planting date and latitude). According to Tancredi et al. (2006), the number of days to flowering is not influenced by removal of the apical meristem when the number of plants per pot is maintained constant. This situation is valid to the present study.

The number of days to flowering in crossing blocks is important to guide studies of plant breeding. Alternative strategies to remedy the group maturity difference in crossing blocks, would be the use of artificial photoperiod control or the use of grafting (SEDIYAMA et al., 1985, LUGÃO, 1988; BORÉM et al., 2009).

Table 4. Summary of analysis of variance and comparisons of means test for number of days from planting to flowering of six soybean parents, in greenhouse, Viçosa-MG, 2009/2010

\begin{tabular}{|c|c|c|}
\hline \multirow{2}{*}{ Variation sources } & \multirow{2}{*}{ Df } & Days from planting to flowering \\
\hline & & $\mathrm{QM}(\mathrm{F} \text { test })^{1}$ \\
\hline Parents & 5 & $701.5472(63.57)^{* *}$ \\
\hline Residue & 82 & 11.03 \\
\hline Parents & & Comparison of means - Tukey Test ${ }^{2}$ \\
\hline NK 7059 RR & & $37.3 \mathrm{c}$ \\
\hline BRSGO 7560 & & $37.7 \mathrm{c}$ \\
\hline TMG 801 & & $45.6 \mathrm{~b}$ \\
\hline BRS Valiosa RR & & $46.3 \mathrm{~b}$ \\
\hline Água-Marinha RR & & $47.6 \mathrm{~b}$ \\
\hline TMG 803 & & $56.8 \mathrm{a}$ \\
\hline Mean & & 46.3 \\
\hline $\mathrm{CV}(\%)$ & & 7.1 \\
\hline
\end{tabular}

Six hundred and seventy-two artificial pollinations were performed in fourteen combinations, in three periods of the day, resulting in approximately 47 pollinations per day. Four hundred and thirty-six pods were obtained without sepals, which correspond to $64.8 \%$ of the total performed pollination.

In the analysis of the fourteen hybrid combinations, it was noticed heterogeneity between the pollination periods to number of performed pollination, pods without sepals and produced seeds, in 10,8 and 12 hybrid combinations, respectively (Table 5). The number of pods from selffertilization may be included in the number of pods without sepals. This occurs because, although pods were harvested only without sepals, at the moment that the artificial pollination was carried out, selffertilization might have already taken place.

In the hybrid combinations TMG $803 \times \mathrm{NK}$ 7059 RR and BRSGO 7560 x NK 7059 RR were observed reduced number of performance pollination, pods without sepals, produced and germinated seeds, hybrid plants between periods of the days (Tables 5). In the hybrid combination TMG 803 x NK 7059 RR the group relative maturity among genitors is very different (see Table 1). So, in the conditions in which the crossing block was conducted, the period of simultaneous flowering between two genitors was coincident in only one day. In BRSGO 7560 x NK 7059 RR, although two parents presented similarity regarding number of days to flowering, the reduced number of pollination occurred due to unavailability of seeds of BRSGO 7560 in the beginning of crossing block installation, resulting in planting only in the three last dates of the crossing block.

Considering the fourteen hybrid combinations and the three pollination periods, seed germination was superior at $84 \%$. In the analysis of hybrid combinations, it was noticed heterogeneity for number of seeds germinated and plants confirmed as hybrid in $62.3 \%$ of hybrid combinations between the pollination periods. 
Table 5. Number of performed pollinations (Pol), number of pods without sepals (Pods) number of produced seeds (Seeds), number of germinated seeds $(\mathrm{G})$ and number of plants confirmed as hybrid $(\mathrm{H})$ in 14 combinations, in three periods, Viçosa-MG, 2009/2010 1 and 2

\begin{tabular}{|c|c|c|c|c|c|c|c|c|}
\hline & \multicolumn{3}{|c|}{ Periods $^{2}$} & \multirow{2}{*}{$\chi^{2}$ test } & \multicolumn{3}{|c|}{ Periods } & \multirow{2}{*}{$\chi^{2}$ test } \\
\hline & H1 & H2 & H3 & & H1 & H2 & H3 & \\
\hline & \multicolumn{4}{|c|}{ TMG 801 x BRS Valiosa RR } & \multicolumn{4}{|c|}{ TMG $803 \times$ BRSGO 7560} \\
\hline Pol. & 17 & 51 & 45 & $17.48 * *$ & 2 & 9 & 4 & $5.20^{\mathrm{n}^{-}-}$ \\
\hline Pods & 7 & 37 & 30 & $19.97 * *$ & 1 & 6 & 1 & $6.25^{*}$ \\
\hline Seeds & 18 & 90 & 79 & $48.26 * *$ & 2 & 12 & 1 & $14.80 * *$ \\
\hline $\mathrm{G}$ & 9 & 45 & 38 & $23.76 * *$ & 2 & 8 & 1 & $7.81 *$ \\
\hline \multirow[t]{2}{*}{$\mathrm{H}$} & 6 & 42 & 34 & $26.14 * *$ & 2 & 7 & 1 & $6.19 *$ \\
\hline & \multicolumn{4}{|c|}{ TMG 801 x Água-Marinha RR } & \multicolumn{4}{|c|}{ Água-Marinha RR x BRS Valiosa RR } \\
\hline Pol. & 16 & 66 & 56 & $30.43 * *$ & 18 & 50 & $44^{-}$ & $15.50 * *$ \\
\hline Pods & 9 & 51 & 38 & $28.30 * *$ & 4 & 29 & 24 & $18.42 * *$ \\
\hline Seeds & 23 & 119 & 97 & $63.49 * *$ & 9 & 51 & 46 & $29.79 * *$ \\
\hline G & 12 & 60 & 45 & $30.92 * *$ & 3 & 51 & 46 & $41.78 * *$ \\
\hline \multirow[t]{2}{*}{$\mathrm{H}$} & 12 & 57 & 44 & $28.47 * *$ & 1 & 49 & 41 & $43.60 * *$ \\
\hline & \multicolumn{4}{|c|}{ TMG $801 \times$ NK 7059 RR } & \multicolumn{4}{|c|}{ NK 7059 RR x BRS Valiosa RR } \\
\hline Pol. & 3 & 14 & 14 & $7.80 * *$ & 5 & 38 & 40 & $27.92 * *$ \\
\hline Pods & 2 & 9 & 10 & $5.42^{\mathrm{ns}}$ & 0 & 29 & 30 & $29.52 * *$ \\
\hline Seeds & 4 & 23 & 27 & $16.77 * *$ & 0 & 74 & 71 & $72.59 * *$ \\
\hline $\mathrm{G}$ & 2 & 12 & 14 & $8.85^{*}$ & 0 & 74 & 69 & $71.76^{* *}$ \\
\hline \multirow[t]{2}{*}{$\mathrm{H}$} & 2 & 12 & 13 & $8.22 *$ & 0 & 61 & 65 & $63.19 * *$ \\
\hline & \multicolumn{4}{|c|}{$T M G 803 \times T M G 801$} & \multicolumn{4}{|c|}{$N K 7059 R R \times$ Água-Marinha $R R$} \\
\hline Pol. & 5 & 14 & 6 & $5.84^{\mathrm{ns}-}$ & 0 & 20 & 25 & $23.33 * *$ \\
\hline Pods & 3 & 9 & 5 & $3.29^{\mathrm{ns}}$ & 0 & 12 & 15 & $14.00 * *$ \\
\hline Seeds & 6 & 22 & 10 & $10.94 * *$ & 0 & 30 & 21 & $27.88 * *$ \\
\hline G & 3 & 14 & 7 & $7.75^{*}$ & 0 & 28 & 18 & $26.26 * *$ \\
\hline \multirow[t]{2}{*}{$\mathrm{H}$} & 2 & 11 & 7 & $6.10 *$ & 0 & 27 & 16 & $25.20 * *$ \\
\hline & \multicolumn{4}{|c|}{$T M G$ 803 $\times$ BRS Valiosa $R R$} & \multicolumn{4}{|c|}{$B R S G O 7560 \times$ BRS Valiosa $R R$} \\
\hline Pol. & 4 & 15 & 7 & $7.46^{*}$ & 2 & 5 & 12 & $8.31 *$ \\
\hline Pods & 2 & 8 & 5 & $3.60^{\mathrm{ns}}$ & 2 & 4 & 10 & $6.50 *$ \\
\hline Seeds & 4 & 15 & 9 & $6.49 *$ & 4 & 8 & 16 & $8.00 *$ \\
\hline $\mathrm{G}$ & 2 & 8 & 5 & $3.6^{\mathrm{ns}}$ & 2 & 4 & 8 & $4.00^{\mathrm{ns}}$ \\
\hline \multirow[t]{2}{*}{$\mathrm{H}$} & 2 & 8 & 3 & $4.76^{\mathrm{ns}}$ & 2 & 4 & 7 & $2.92^{\mathrm{ns}}$ \\
\hline & \multicolumn{4}{|c|}{ TMG 803 x Água-Marinha $R R$} & \multicolumn{4}{|c|}{ BRSGO $7560 \times$ Água-Marinha $R R$} \\
\hline Pol. & 4 & 18 & 10 & $9.25 * *$ & 2 & 9 & $16^{-}$ & $10.88 * *$ \\
\hline Pods & 3 & 12 & 5 & $6.70 *$ & 2 & 8 & 8 & $3.99^{\mathrm{ns}}$ \\
\hline Seeds & 4 & 24 & 10 & $16.63 * *$ & 5 & 19 & 17 & $8.39 *$ \\
\hline $\mathrm{G}$ & 2 & 12 & 5 & $8.31 *$ & 3 & 10 & 9 & $3.90^{\mathrm{ns}}$ \\
\hline \multirow[t]{2}{*}{$\mathrm{H}$} & 2 & 7 & 4 & $2.92^{\mathrm{ns}}$ & 3 & 9 & 9 & $3.42^{\mathrm{ns}}$ \\
\hline & \multicolumn{4}{|c|}{$T M G 803 \times N K 7059 R R$} & & $G O$ & $N K$ & \\
\hline Pol. & 0 & 2 & 2 & $2.00^{\mathrm{ns}-1}$ & 0 & 1 & 1 & $1.00^{\mathrm{n} \mathrm{s}^{-}}$ \\
\hline Pods & 0 & 2 & 2 & $2.00^{\mathrm{ns}}$ & 0 & 1 & 1 & $1.00^{\mathrm{ns}}$ \\
\hline Seeds & 0 & 3 & 3 & $3.00^{\mathrm{ns}}$ & 0 & 2 & 2 & $2.00^{\mathrm{ns}}$ \\
\hline $\mathrm{G}$ & 0 & 3 & 3 & $3.00^{\mathrm{ns}}$ & 0 & 2 & 2 & $2.00^{\mathrm{ns}}$ \\
\hline $\mathrm{H}$ & 0 & 3 & 0 & $6.00 *$ & 0 & 2 & 2 & $2.00^{\mathrm{ns}}$ \\
\hline
\end{tabular}

${ }^{* * *}$, and ns Significant at 1\%, 5\% and non-significant, respectively, by $\chi^{2}$ test; ${ }^{2} \mathrm{H} 1:$ 8:00 - 10:00 a.m., H2: 10:00 - 12:00 a.m. and H3: 2:00 - 4:00 p.m.

In the three pollination periods and within these periods in fourteen hybrid combinations the normality test (Lilliefors) showed not reasonable to study the data by normal distribution for the number of performed pollinations, pods without sepals, produced seeds, germinated seeds, plants confirmed as hybrid and percentage of pods without sepals. Therefore, the original data were transformed in $\log (\mathrm{x}+0.5)$. Posteriorly, by Lilliefors and Cochran tests, both at $5 \%$ probability, indicated possible to analyse data considering normal distribution and with homogeneity of variance, respectively.

Non-significant result was observed ( $>0.05$ ) by Scheffé test in contrasts $\mathrm{H} 2-\mathrm{H} 3$ for variables: number of performed pollinations, pods without sepals, produced seeds, germinated seeds 
and plants confirmed as hybrid; whereas, for contrasts $\mathrm{H} 1-\mathrm{H} 2$ and $\mathrm{H} 1-\mathrm{H} 3$ the result was significant (Table 6). This allows affirming that periods $\mathrm{H} 2$ and $\mathrm{H} 3$ presented similar means, however, higher when compared with pollination period $\mathrm{H} 1$.

The reduced number of pods without sepals originating from the hybridization in $\mathrm{H} 1$ can be explained due to the fact that in this period the pollen is probably in massulae, and thus, not powdered. In addition to this fact, the stigma probably presents higher receptivity in the $\mathrm{H} 2$ and $\mathrm{H} 3$ periods, increasing the success of crosspollinations. This agrees with Sediyama et al. (1981), Sediyama et al. (2005), Young and Gravitz (2002) and Borém et al. (2009) that reported higher success rates of pollination performance in the afternoon due to pollen liberation and stigma receptivity.

Table 6. Means of groups $\mathrm{H} 1, \mathrm{H} 2$ and $\mathrm{H} 3$ and different contrasts (Contrast) according to number of performed pollinations (Pol), number of pods without sepals (Pods), number of produced seeds (Seeds), number of germinated seeds (Germinated), number of seedlingd confirmed as hybrid (Hybrids) and percentage of pods without sepals (PPWS), Viçosa-MG, 2009/2010

\begin{tabular}{|c|c|c|c|c|c|c|}
\hline \multirow{2}{*}{ Variables } & \multicolumn{3}{|c|}{ Times ${ }^{1 \mathrm{e} 2}$} & \multicolumn{3}{|c|}{ Contrasts $^{2}$} \\
\hline & H1 & $\mathrm{H} 2$ & H3 & $\mathrm{H} 1-\mathrm{H} 2$ & H1-H3 & $\mathrm{H} 2-\mathrm{H} 3$ \\
\hline Pol. & 0.5250 & 1.1561 & 1.1060 & $-0.6311^{*}$ & $-0.5811^{*}$ & $0.0500^{\mathrm{ns}}$ \\
\hline Pods & 0.2970 & 1.0196 & 0.9340 & $-0.7226^{*}$ & $-0.6371^{*}$ & $0.0855^{\mathrm{ns}}$ \\
\hline Seeds & 0.4983 & 1.3331 & 1.1987 & $-0.8348^{*}$ & $-0.7004^{*}$ & $0.1344^{n}$ \\
\hline Germinated & 0.3209 & 1.1649 & 1.0402 & $-0.8440^{*}$ & $-0.7193^{*}$ & $0.1248^{n}$ \\
\hline Hybrids & 0.2724 & 1.1229 & 0.9405 & $-0.8505^{*}$ & $-0.6681^{*}$ & $0.1825^{\mathrm{n}}$ \\
\hline PPWS & 1.1727 & 1.8612 & 1.8170 & $-0.6884^{*}$ & $-0.6443^{*}$ & $0.0441^{\mathrm{n}}$ \\
\hline
\end{tabular}

${ }^{1}$ H1: 8:00 - 10:00 a.m., H2: 10:00 - 12:00 a.m. and H3: 2:00 - 4:00 p.m.; ${ }^{2}$ Original values transformed in $\log (\mathrm{x}+0.5) ;{ }^{3 \mathrm{~ns}}$ and $*$ Nonsignificant and significant, respectively, at $5 \%$ probability by Scheffé Test.

The percentage of pods without sepals mean was superior to identified by Volmann et al. (1992). These authors identified pods originating from artificial pollination based on sepal absence and, subsequently, carried out planting of seeds of these pods to quantify the number of hybrid plants for hypocotyl color analysis. Approximately $64 \%$ of pods containing hybrid seeds were obtained when female flowers were emasculation and pollinated, and only $18 \%$ of efficiency when pollination was carried out with the naked eye and without emasculation.

High temperatures are frequent and important causes of abortion of fertilized ovule and consequently not development of pods, i.e at $40{ }^{\circ} \mathrm{C}$, from $57 \%$ to $71 \%$ of pods can be aborted (MÜLLER, 1981). According to Rosolen (2006), the best temperature for ovule fertilization and development of pods is $30^{\circ} \mathrm{C}$ during the day and 20 ${ }^{\circ} \mathrm{C}$ at night.

In periods $\mathrm{H} 2$ and $\mathrm{H} 3$ good environmental conditions (relative moisture and air temperature) were observed, both for plant development and for the operator, collaborating for the efficiency of artificial pollination. In other words, pollen is powdered and it is easier to identify feminine flowers in appropriate stage, associated to better work conditions. According to Sediyama et al. (1981), even when the best methodologies are employed by experienced technicians, the success of artificial pollination varies greatly according to the environmental conditions.

An experienced, careful and skillful operator can obtain over $90 \%$ success percentage in the performed pollinations (BORÉM et al., 2009). The factor operator skill, in this study, was of great importance in obtaining the hybrid seeds. High efficiency of artificial pollination was observed both in hybrid combinations that originated many seeds and in those which originated few seeds. Hence, the correlation between the total number of pods without sepals and the total number of hybrid seeds was $0.9229(\mathrm{p}<0,01$, by $\mathrm{t}$ test and Mantel test with 5000 simulation). If the operator is very skilled, it is possible to obtain hybrid seeds even when there is a reduced number of genitor plants and when pollination is performed in inappropriate times of the day.

\section{CONCLUSIONS}

Artificial pollinations performed in January, with parent used in this study, were more efficient in the period from 10:00 to 12:00 a.m., with mean relative moisture of $34.1 \%$ and mean temperature of $38.5^{\circ} \mathrm{C}$ and 2:00 to 4:00 p.m. with $30.7 \%$ and 41.6 ${ }^{\circ} \mathrm{C}$ respectively for relative moisture and means of temperature.

Best hybrid combinations were: TMG $801 \mathrm{x}$ BRS Valiosa RR, TMG 803 x BRSGO 7560, TMG 
801 x Água-Marinha RR, BRSGO 7560 x BRS Valiosa RR, TMG $801 \times$ NK 7059 RR, NK 7059 RR x BRS Valiosa RR, TMG 803 x BRS Valiosa RR and NK 7059 RR x Água-Marinha RR.

\section{ACKNOWLEDGEMENTS}

The authors thank the National Council for Scientific and Technological Development (CNPq); the Coordination for Improvement of Higher Education Personnel (CAPES) for doctoral and productivity fellowships; and to the Minas Gerais State Research Foundation (Fapemig) for financial support to project APQ-01987-10 (Process number 01/2010 - Universal Demand)

RESUMO: A hibridação é um importante método de melhoramento utilizado na cultura da soja. No entanto, são poucas as informações sobre a magnitude da umidade relativa e da temperatura do ar recomendadas para a atividade de polinização artificial. Portanto, objetivou-se determinar a eficiência da hibridação artificial entre genitores de soja em função de diferentes períodos do dia. Efetuaram-se, em casa de vegetação, polinizações artificiais em 14 combinações híbridas em três períodos do dia. Os genitores utilizados foram: TMG 801, TMG 803, BRSGO 7560, BRS Valiosa RR, Água-Marinha RR e NK 7059 RR. As variáveis estudadas foram: umidade relativa, temperatura do ar, número de dias para o florescimento, polinizações artificiais efetuadas, vagens sem sépala, sementes produzidas, sementes germinadas, plantas híbridas e porcentagem de vagens sem sépalas. Os dados foram submetidos ao teste de normalidade e homogeneidade de variância, análise de variância, testes de Tukey, de Scheffé e $\chi^{2}$ e análise de correlação. Foram efetuadas 672 polinizações artificiais, nas quais se obtiveram 436 vagens sem sépala. Aproximadamente, $90 \%$ das sementes produzidas foram híbridas. Os resultados indicaram que as polinizações artificiais realizadas em janeiro, com os genitores do presente estudo, foram mais eficientes no período das $10: 00 \mathrm{~h}$ às $12: 00 \mathrm{~h}$, com umidade relativa média de $34,1 \%$ e temperatura média de $38,5^{\circ} \mathrm{C}$ e das $14: 00 \mathrm{~h}$ às $16: 00 \mathrm{~h}$ com $30,7 \%$ e $41,6^{\circ} \mathrm{C}$, respectivamente para umidade relativa e temperatura média.

PALAVRAS-CHAVE: Glycine max. Melhoramento. Variabilidade genética.

\section{REFERENCES}

BORÉM, A.; ALMEIDA, L. A.; KIIHL, R. A. S. Hibridação em soja. In: BORÉM, A. (Ed.). Hibridação artificial de plantas. Viçosa: Editora UFV, 2009. p. 514-536.

CONAB - Companhia Nacional do Abastecimento. Acompanhamento de safra brasileira: grãos. Nono levantamento. Conab: Brasília-DF, junho, 2013. Disponível em:

http://www.conab.gov.br/OlalaCMS/uploads/arquivos/13_06_06_09_09_27_boletim_graos_-_junho_2013.pdf. Acesso em: 22 jul. 2013.

CONAB - Companhia Nacional do Abastecimento. Séries históricas: Cultura da Soja. 2011. Disponível em: http://www.conab.gov.br/OlalaCMS/uploads/arquivos/11_04_12_11_17_51_sojaseriehist..xls. Acesso em: 26 abr. 2011.

CRUZ, C. D. GENES - a software package for analysis in experimental statistics and quantitative genetics. Acta Scientiarum. Agronomy, Maringá, v. 35, n. 3, p. 271-276, july/sept. 2013.

EMBRAPA - Empresa Brasileira de Pesquisa Agropecuária. Tecnologias de produção de soja - Região Central do Brasil - 2008. Londrina: Embrapa Soja, Embrapa Cerrados and Embrapa Agropecuária Oeste, 2008. $280 \mathrm{p}$.

FEHR, W.R.; CAVINESS, C.E. Stages of soybean development. Ames: Iowa State University of Science and Technology, 1977. 12 p. (Special Report 80).

FUNDAÇÃO MT. Cultivares de soja. 2011 Disponível em:

< http://www.fundacaomt.com.br/soja/> Acesso em: 14 de maio de 2011. 
JOHNSON, H. W.; BERNARD, R. L. Soybean genetics and breeding. In: NORMAN, A. G. (Ed.). The soybean. New York: Academic Press Inc, 1963. p. 1-73.

LUGÃO, S. M. B. Eficiência da enxertia na precocidade de floração de soja (Glycine max (L.) Merrill) para fins de hibridação. 1988. 61 f. Dissertação (Mestrado em Fitotecnia) - Curso de Pós-Graduação em Fitotecnia, Universidade Federal de Viçosa, Viçosa, 1988.

MIYASAKA, S.; SILVA, J. G. Melhoramento da Soja II: Melhoramento por hibridação. Bragantia, Campinas, v. 17, n. 16, p. 213-224, dez. 1958. http://dx.doi.org/10.1590/S0006-87051958000100016

MÜLLER, L. Taxonomia e morfologia. In: MIYASAKA, S.; MEDINA, J. C. A. (Eds.). A soja no Brasil. Campinas: Instituto de Tecnologia de Alimentos, 1981. p. 65-104.

PIEROZZI, P. H. B.; RIBEIRO, A. S.; MOREIRA, J. U. V.; LAPERUTA, L. D. C.; RACHID, B. F.; LIMA, W. F.; ARIAS, C. A. A.; OLIVEIRA, M. F.; TOLEDO, J. F. F. New soybean (Glycine max Fabales, Fabaceae) sources of qualitative genetic resistance to Asian soybean rust caused by Phakopsora pachyrhizi (Uredinales, Phakopsoraceae). Genetics and Molecular Biology, São Paulo, v. 31, n. 2, p. 505-511, 2008.

http://dx.doi.org/10.1590/S1415-47572008000300018

ROSOLEM, C. A. Ecofisiologia da Soja In: SUZUKI, S.; YUYAMA, M. M.; CAMACHO, S. A. (Eds.). Fundação MT - Boletim de Pesquisa de Soja 2006. Rondonópolis: Fundação MT, 2006. p. 41-51.

SEDIYAMA, T.; ALMEIDA, L. A.; MIYASAKA, S.; KIIHL, R. A. S. Genética e Melhoramento. In: MIYASAKA, S; MEDINA, J. C. (Eds.). A soja no Brasil. Campinas: Instituto de Tecnologia de Alimentos, 1981. p. 209-226.

SEDIYAMA, T.; PEREIRA, M. G.; SEDIYAMA, C. S.; GOMES, J. L. L. Cultura da soja - Parte I. Viçosa: Imprensa Universitária da Universidade Federal de Viçosa, 1985. 96 p.

SEDIYAMA, T.; TEIXEIRA, R. C.; REIS, M. S. Melhoramento da Soja. In: BORÉM, A. (Ed.).

Melhoramento de Espécies Cultivadas. Viçosa: Editora UFV, 2005. p. 551-603.

SILVA, F. A. S.; AZEVEDO, C. A. V. Versão do programa computacional Assistat para o sistema operacional Windows. Revista Brasileira de Produtos Agropecuários, Campina Grande, v. 4, n. 1, p. 71-78, 2002. http://dx.doi.org/10.15871/1517-8595/rbpa.v4n1p71-78

SYNGENTA SEEDS. Cultivares de soja. 2011. Disponível em:

http://www.syngenta.com/country/br/pt/produtosemarcas/sementes/grandes-culturas/soja/Pages/home.aspx. Acesso em: 14 maio 2011.

TANCREDI, F. D.; SEDIYAMA, T.; REIS, M. S.; CECON, P. R.; TEIXEIRA, R. C. Influência da remoção do meristema apical sobre os componentes de produtividade em população de soja. Acta Scientiarum.

Agronomy, Maringá, v. 26, n. 1, p. 113-119, jan./mar. 2004.

TANCREDI, F. D.; SEDIYAMA, T.; REIS, M. S.; CECON, P. R.; TEIXEIRA, R. C. Efeito da remoção do meristema apical no crescimento e desenvolvimento de plantas de soja em condições de casa de vegetação. Bioscience Journal, Uberlândia, v. 22, n. 2, p. 53-60, May/Aug. 2006.

VOLLMANN, J.; GRUBER, H.; GRETZAMANCHER, R.; RUCKENBAUER, P. Note one the efficiency of artificial hybridization in soybean. Bodenkultur, v. 43, p. 123-127, 1992.

YOUNG, H. J; GRANVITZ, L. The effects of stigma age on receptivity in Silene alba (Caryophyllaceae). American Journal of Botany, v. 89, n. 8, p. 1237-1241, Aug. 2002. http://dx.doi.org/10.3732/ajb.89.8.1237 